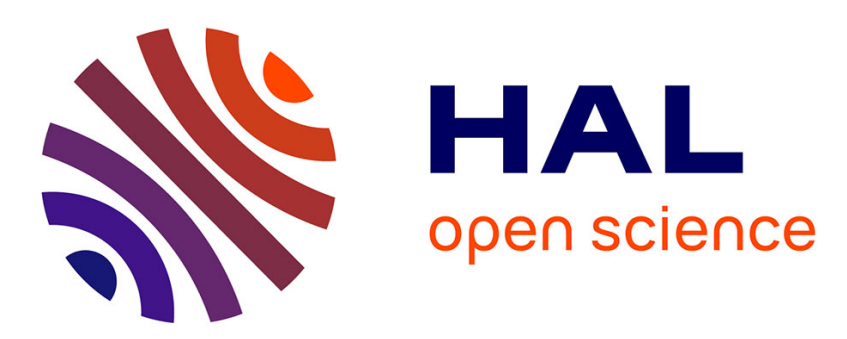

\title{
Structural Investigation of Amorphous Ni2B by EXAFS and XRD
}

L. Ma, W. Huang, J. Yang, J. Deng

\section{To cite this version:}

L. Ma, W. Huang, J. Yang, J. Deng. Structural Investigation of Amorphous Ni2B by EXAFS and XRD. Journal de Physique IV Proceedings, 1997, 7 (C2), pp.C2-909-C2-910. 10.1051/jp4:1997276 . jpa-00255359

\section{HAL Id: jpa-00255359 https://hal.science/jpa-00255359}

Submitted on 1 Jan 1997

HAL is a multi-disciplinary open access archive for the deposit and dissemination of scientific research documents, whether they are published or not. The documents may come from teaching and research institutions in France or abroad, or from public or private research centers.
L'archive ouverte pluridisciplinaire HAL, est destinée au dépôt et à la diffusion de documents scientifiques de niveau recherche, publiés ou non, émanant des établissements d'enseignement et de recherche français ou étrangers, des laboratoires publics ou privés. 


\title{
Structural Investigation of Amorphous $\mathrm{Ni}_{2} \mathrm{~B}$ by EXAFS and XRD
}

\author{
L. Ma, W. Huang, J. Yang* and J. Deng* \\ Research Center for Analysis and Measurement, Fudan University, 220 Handan Road, Shanghai 200433, \\ China \\ * Department of Chemistry, Fudan University, 220 Handan Road, Shanghai 200433, China
}

\begin{abstract}
The structure and thermostability of hyperfine amorphous $\mathrm{Ni}_{2} \mathrm{~B}$ catalysts $\left(\mathrm{HA}-\mathrm{Ni}_{2} \mathrm{~B}\right)$ have been studied by EXAFS, XPD and DSC. The samples prepared by chemical reduction have been proved to be amorphous. The grain size is between $5 \mathrm{~nm}$ and $20 \mathrm{~nm}$. A short-range order cluster is formed. The distances of Ni-B or Ni-Ni did not alter due to the change of the conditions but the coordination number of $\mathrm{Ni}$ is changed. The $\mathrm{HA}-\mathrm{Ni}_{2} \mathrm{~B}$ is only stable up to $140^{\circ} \mathrm{C}$. Over $140^{\circ} \mathrm{C}$, the crystal $\mathrm{Ni}$ and an intermediate formed. Finally the intermediate disappears but some $\mathrm{B}_{2} \mathrm{O}_{3}$ can be detected.
\end{abstract}

\section{Introduction}

Hyperfine amorphous catalysts have been paid attention for both of hyperfine and amorphous features. By EXAFS A. Gorrias et al. [1] studied the hyperfine amorphous $\mathrm{Fe}-\mathrm{Co}-\mathrm{B}$ alloy prepared by chemical reduction. They found a $\alpha$-Fe-like cluster of Fe$\mathrm{Co}-\mathrm{B}$ and $\mathrm{Co}$ atoms replaced $\mathrm{Fe}$ atoms in $\alpha$-Fe. J. Jiang [2] compared a hyperfine amorphous alloy of $\mathrm{Fe}_{79 \mathrm{~B}_{21}}$ with a banded quenching amorphous $\mathrm{Fe} 8 \mathrm{~B}_{2} \mathrm{~B}_{20}$. The former has better isotropism and the number of $\mathrm{B}$ atoms about Fe atoms is larger than in the later. P.C. Maybury [3] reported that the amorphous compounds of $\mathrm{Ni}_{2} \mathrm{~B}$ and $\mathrm{Co}_{2} \mathrm{~B}$ can absorb more hydrogen than the crystal. If fresh Co-B alloy is put in water, hydrogen can be released and boric acid is formed. B. Ganem [4] reported that when amorphous $\mathrm{Ni}-\mathrm{B}$ was heated to $250^{\circ} \mathrm{C}$, the crystal $\mathrm{Ni}, \mathrm{Ni} 2 \mathrm{~B}$ or $\mathrm{Ni} 3 \mathrm{~B}$ formed. R.C. Wade [5] found that boron disappears in the crystallization. The purpose of this paper is to study the influence of the solvents and the temperature on the structure of hyperfine amorphous $\mathrm{Ni}_{2} \mathrm{~B}$ catalysts $\left(\mathrm{HA}-\mathrm{Ni}_{2} \mathrm{~B}\right.$ ) and to study the thermostability of $\mathrm{HA}-\mathrm{Ni}_{2} \mathrm{~B}$.

\section{Experiment}

\subsection{Sample preparation}

Drop the basic solution of $\mathrm{KBH} 4$ into the solution of $\mathrm{Ni}(\mathrm{AC})_{2} 4 \mathrm{H}_{2} \mathrm{O}$. The hyperfine amorphous $\mathrm{Ni} 2 \mathrm{~B}$ alloy is formed. Three samples were prepared: (1) in anhydrous alcohol at $25^{\circ} \mathrm{C},(2)$ in water at $25^{\circ} \mathrm{C}$, (3) in anhydrous alcohol at $2^{\circ} \mathrm{C}$.

\subsection{Extended X-ray absorption fine structure (EXAFS)}

The absorption data of Ni K edge were collected at the BL-10B beamline in Photon Factory, Japan. The electron energy is 2.5 $\mathrm{GeV}$. The current is $300 \mathrm{~mA}$. The monochromator is a channel-cut $\mathrm{Si}(311)$ crystal monochromator, $\mathrm{d}=0.163747 \mathrm{~nm}$. The data was collected from $7831 \mathrm{eV}$ to $9431 \mathrm{eV}$. We registered data three times for estimating the deviation. Data was processed by the program package FXEA [6.7]. The code FEFF [8] was used to calculate the theoretical $f_{j}(k), \lambda_{j}(k)$ and $\phi_{j}(k)$.

\subsection{X-ray powder diffraction (XPD)}

The XPD was carried out with a powder diffractometer D/MAX-rB manufactured by Rigaku, Japan (Cu K $\alpha$ radiation, $40 \mathrm{kV}$, $100 \mathrm{~mA}$, graphite monochromator, DS $1^{\circ}$, SS $1^{\circ}$, RS $0.15 \mathrm{~mm}$ ).

\section{Results and discussion}

\subsection{The structure of alloys prepared at different conditions}

3.1.1 The XPD patterns of three samples showed us that there were two very diffused peaks in them, so they are amorphous.

3.1.2 Radius structure functions (RSF) of EXAFS are shown in Fig.1. The structure parameters obtained by curve fitting the filtered diagrams are listed in Table 1.

On RSF there is only one strong coordination peak (fig.1). It means that there is only short-range order and all the samples are amorphous. Comparing the $\sigma$ of different coordination shells in Table $1, \sigma$ increases rapidly from 0.004 to 0.012 following the increase of bonding length. It is more evidence of short-range order. 
Table 1 Structure Parameters from EXAFS

\begin{tabular}{lllll} 
& $r(n m)$ & $C N$ & $\sigma\left(\mathrm{nm}^{-1}\right)$ & $\Delta E_{0}(e v)$ \\
Sample & \multicolumn{5}{c}{$(1)$} & \\
Ni--B & $0.208(2)$ & $2.1(3)$ & $0.003(1)$ & $-0.6(2)$ \\
Ni--Ni & $0.218(4)$ & $1.5(3)$ & $0.008(1)$ & $-0.6(2)$ \\
Ni--Ni & $0.252(4)$ & $1.0(2)$ & $0.013(2)$ & $-0.6(2)$ \\
Sample & \multicolumn{5}{c}{$(2)$} \\
Ni--B & $0.208(3)$ & $4.0(4)$ & $0.004(1)$ & $-3.0(3)$ \\
Ni-Ni & $0.217(3)$ & $1.8(3)$ & $0.008(1)$ & $-3.0(3)$ \\
Ni-Ni & $0.251(5)$ & $1.6(3)$ & $0.012(3)$ & $-3.0(3)$ \\
Sample & \multicolumn{5}{c}{$(3)$} & & \\
Ni--B & $0.208(2)$ & $4.0(4)$ & $0.007(1)$ & $-4.2(2)$ \\
Ni-Ni & $0.218(3)$ & $0.7(2)$ & $0.008(2)$ & $-4.2(2)$ \\
Ni-Ni & $0.254(4)$ & $3.8(5)$ & $0.011(2)$ & $-4.2(2)$
\end{tabular}

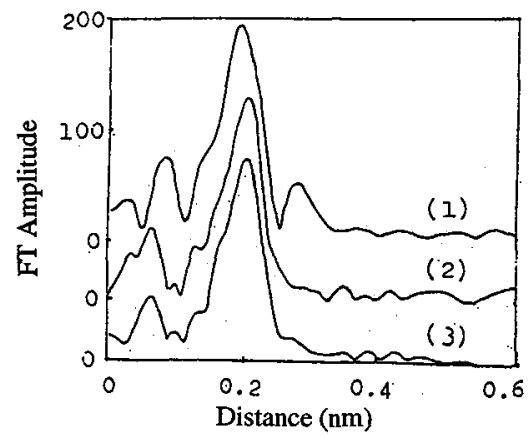

Fig.1 RSF of samples (1), (2), (3)

3.1.3 From the structural parameters we got : (1) $\mathrm{rNi}-\mathrm{B}$ for the three samples is the same $(0.208 \mathrm{~nm})$. It is shorter than the sum of the atom radii of nickel and boron $(0.217 \mathrm{~nm})$. It means that a strong interaction exists between the nickel atom and the boron atom. (2) The nearest distance between two nickel atoms $\mathrm{rNi}-\mathrm{Ni}$ is $0.218 \mathrm{~nm}$. It is still the same for all three samples. It is shorter than $0.250 \mathrm{~nm}$ and $0.230 \mathrm{~nm}$ which are the sum of two metal radii in metallic Ni and two covalence radii of nickel atom respectively. It also means that a very strong interaction exists between nickel atoms. We conclude that there is a cluster of $\mathrm{Ni}-\mathrm{B}$ in alloy.

The second distance of $\mathrm{Ni}-\mathrm{Ni}(\mathrm{r}(\mathrm{Ni}-\mathrm{Ni}) 2)$ is $0.252 \mathrm{~nm}$. It is close to the distance between nearest nickel atoms in metal nickel. It may mean that very fine grains of metallic nickel mix with the Ni-B cluster or it is the second Ni coordination shell in $\mathrm{Ni}-\mathrm{B}$ alloy.

3.1.4 The $\mathrm{r}_{\mathrm{Ni}-\mathrm{B}}, \mathrm{r}_{\mathrm{Ni}-\mathrm{Ni}}$ and $\mathrm{r}_{(\mathrm{Ni}-\mathrm{Ni}) 2}$ distances for the three samples are the same in the range of experimental deviation. It means that the change of preparation conditions does not affect the interaction between $\mathrm{Ni}-\mathrm{B}$ and Ni-Ni. But the coordination numbers of the three samples are different. The CNs of sample 1 are smaller than the other two. It means that the size and the structure of cluster Ni-B changes with the change of the conditions. The grain size is between 5-20 nm measured in the photo of TEM. Our data are close to the data of S.N. Ishamaev [9], P. Lanparter [10], P. Kazler [11] and J. Wang [12], but they are a little smaller. The reason may be that our grains are nanometersized, i.e. much smaller than theirs.

\subsection{The thermostability and the crystallization of HA-Ni2 B}

By the hyperfine and amorphous features the materials has high surface energy. It makes the structure unstable. We studied the thermostability by DSC, XPD and EXAFS.

On DSC diagram there are three exothermic peaks located at $144^{\circ} \mathrm{C}, 235^{\circ} \mathrm{C}$ and $341^{\circ} \mathrm{C}$. It means that the catalyst is only stable below $140^{\circ} \mathrm{C}$ which is lower than stable temperature of quenched $\mathrm{Ni}_{2} \mathrm{~B}$. From the phase analysis of samples which were obtained by heating the sample (1) at different temperatures $\left(100^{\circ} \mathrm{C}, 140^{\circ} \mathrm{C}, 250^{\circ} \mathrm{C}, 350^{\circ} \mathrm{C}\right.$ and $\left.500^{\circ} \mathrm{C}\right)$, it is found that the $\mathrm{HA}-\mathrm{Ni}_{2} \mathrm{~B}$ changed to crystal $\mathrm{Ni}$ and $\mathrm{Ni} 3 \mathrm{~B}$ over $140^{\circ} \mathrm{C}$. At $350^{\circ} \mathrm{C}$, Ni3 $\mathrm{B}$ changed further. An unknown intermediate formed. When the temperature reached $500^{\circ} \mathrm{C}, \mathrm{Ni3} B$ and the intermediate disappeared. All Ni changes to crystal and part of $\mathrm{B}$ transfers to $\mathrm{B}_{2} \mathrm{O}_{3}$.

From EXAFS, we found that after heating the distances between $\mathrm{Ni}$ and $\mathrm{B}$ or $\mathrm{Ni}$ are the same as before heating while the $\mathrm{CNs}$ are larger than before heating. It means that the cluster of $\mathrm{Ni}-\mathrm{B}$ is enlarged after heating.

\section{Acknowledgments}

We greatly appreciate Prof. M.Nomura for his kind help when we made the experiments in Photon Factory.

\section{References}

[1] A.Gorrias, G.Ennas, G.Licheri, G.Marongiu, A.Musinu, G.Paschina, G.Piccaluga, G.Pinna, M.Magini, J. Mater. Sci. Lett., 7 (1988) 407

[2] J.Jiang, I.Denzi, U.Gonser, X.Lin, J. Non-Cryst. Solids, 124 (1990) 139

[3] P.C.Maybury, R.W.Mitchell, M.F.Hawthorne, J. Chem. Soc. Chem. Commun., 13 (1974) 534

[4] B.Ganem, J.O.Osby, Chem. Rev., 86 (1986) 763

[5] R.C.Wade, D.G.Holah, A.N.Hughes, B.C.Hui, Catal. Rev.Sci. Eng., 14 (1976) 211

[6] Kang Lu and Lidun Ma, Analytica Chemica Acta, 210 (1989) 143

[7] Chen Jie, Lu Gang and.Ma Lidun, J.of Fudan University (Nature Science), 28(1) (1989) 76

[8] J.J.Rehr, J.Mustredeleon, S.I.Zabinsky, R.C.Albers, J.Am.Chem.Soc., 113 (1991) 5136

[9] S.N.Ishmaev, S.L.Iskov, I.P.Sadikov, E.Avab, L.Koszegi, A.Lovas, Gy. Meszaros, J. Non-Cryst. Solids, 94 (1987) 11

[10] P.Lanparter, W.Sperl, S.Steeb, J.Bletry, Z. Naturforsch, 37a (1982) 1223

[11] P.Kizler, Phys. Rev. Lett., 67 (1991) 3555

[12] J.Wong, H.H.Liebermann, Phys. Rev. B, 29 (1984) 651 